\title{
Utilization of Higher Education Budget: Study on Public Universities in Bangladesh
}

\author{
Dr Shakhawat Hossain Sarkar ${ }^{1}$, Dr Syed Zabid Hossain ${ }^{2}$ \\ ${ }^{1}$ Associate Professor, Department of Accounting and Information Systems, Jatiya Kabi Kazi Nazrul Islam \\ University, Trishal, Mymensingh 2220, Bangladesh. \\ ${ }^{2}$ Professor, Department of Accounting and Information Systems, University of Rajshahi, Rajshahi 6205, \\ Bangladesh.
}

\begin{abstract}
This study appraises utilization of higher education budget considering session jam in public universities, unemployment of university graduates and employment nature of university graduates as independent variables and utilization of budget, in light of productive and unproductive, as dependent variable. Empirical results reveal that a large part of higher education budget is inoperative due to short-term and longterm unemployment, session jam and incompatible job nature. Investments of the government and guardians are idle for the period of unemployment of higher education graduates. Concomitantly, session jam creates multidimensional losses of the stakeholders- government and guardians are forced to bear an additional expenditure, students are also compelled to lose potential earnings and delayed in starting their working life, and the country is deprived of getting the service of those graduates for the period of session jam. When technical graduates are employed in general jobs, their skills and efficiency is not utilized properly and around 40 to 45 percent of their higher education expense should be treated as unproductive because technical graduates consume 3 to 5 times higher budget than general graduates.
\end{abstract}

Keywords: Utilization of Budget, Session Jam, Unemployment, Employment Nature, Public University, Bangladesh.

\section{Introduction}

Higher education (HE) contributes to the economic and social development through transforming unskilled population into human resources (HR). Usually expenditure in higher education is considered as an investment and as such it must be well planned and well utilized in order to reap maximum return/ dividend. Human beings are transformed into human resources through tertiary education. HE consumes a huge amount of public and private funds to transform human burden into human asset and in the process of transformation, a significant portion of HE budget is utilized unproductively due to existing job pattern, session jam in higher educational institutions, and unemployment of $\mathrm{HE}$ graduates for short-term and long-term. But, how much amount of HE budget is utilized unproductively has not yet been identified through a scientific method. Above situations come up with the following questions:

How much budget for HE is misused due to session jam, unemployment, and job nature? And what are the financial consequences of session jam, unemployment, and job nature on higher education graduates and or their guardians? The objective of this study is to ascertain the portion of HE budget is utilized unproductively due session jam, unemployment, and job nature. The answer to the above questions is the findings of this study.

\section{Background of the Study}

Education is the basic need for self-development, socio-economic transformation, and advancement of a country and it is also the prime ingredient of HRD (Khatun, 2003). It is generally believed that education contributes to economic growth through training and acquisition of skill, and it is an instrument of poverty reduction (Adawo, 2011, p.46 \& 55). The goal and mission of HE are numerous, complex, highly debated, and varied by discipline and stakeholders (Baldwin \& McCracken, 2013, p.181). In this era of globalization when intellectual capital is increasingly prized, both for individuals and nations, HE has become truly important because it can produce critical thinkers and innovators, as well as healthy, informed and engaged citizens (Chaudhary, Iqbal, \& Gillani, 2009). Universities produce HR with skills and technical know-how that expedite economic and social development of a country (UGC, 2006, p.11). The purpose of HE is to generate and innovate knowledge, and simultaneously to build up skilled manpower (GOB, 2010, p.23). Well trained HR accelerates economic productivity and consequently, generates resources to invest in HE development (Shin, 2012).

According to Heckman (2005) an investment strategy that emphasizes physical capital over human capital fails to capture the benefits that arise from a more balanced investment strategy. Human capital has a high rate of return/ dividend. Education is universally recognized as an investment in HR (Rao, 2006, p.19). HE 
consumes a large portion of public and private funds to ensure economic development, but because of existing job pattern in Bangladesh and requirements placed in recruitment, contribution from HE is not satisfactory (Alam, Khalifa, \& Shahjamal, 2009). A large number of job advertisement such as Bangladesh Civil Service (BCS) general cadre, non cadre $1^{\text {st }}$ class and $2^{\text {nd }}$ class executive jobs under Public Service Commission (PSC) recruitment, Bangladesh Bank and other Government owned banks etc. require only graduation or post graduation from any discipline. Due to the conditions of job advertisements and job crisis in technical fields and or personal interest, technical graduates compete with non technical graduates. Examination system of those jobs gives some advantages to the technical graduates especially science graduates. According to the nature of those jobs, technical graduates are not essential, but they are opted for those non-technical jobs due to job crisis and faulty recruitment system. But the objective of technical university is to produce graduates for contributing to technical fields. It should be mentioned here that the yearly per student government expenditure in technical universities is several times higher than general universities.

The study has both theoretical and practical value. From the theoretical point of view the study will add value to the existing literature on education budgeting in Bangladesh. From the practical point of view this study will help the public university authorities to reduce the misuse of public money through reducing session jam and will also help the manpower policy planners' to take suitable policy measures considering employment opportunities in different field of studies both at home and in abroad for better employment of HR as well as productive utilization of $\mathrm{HE}$ budget.

\section{Review of Literature}

This section presents review of related available literature at home and in abroad to find out the research gap, formulating research questions and to limit the scope of the present research. The substance of the literature review is summarized below keeping an eye on the above needs.

Chauhan (2008) mentioned that SAARC countries have some common social and economic problems, including low literacy rate, poor infrastructure, and substandard quality of education, heavy dropout rates, and inadequate funding. Almost all SAARC countries have been financing their education out of public funds, but allocation of public funds for education is very low, between 2 to 4 percent of GNP as against UNESCO standard of 4 percent of GNP for developing nations. Khan (2009) identified that the low investment is one of the major problems for HRD in South Asia. Sarkar, Rana and Zitu (2013) addressed the challenges of quality $\mathrm{HE}$ in public universities of Bangladesh considering teaching aids, library facilities, availability of books and journals, research facilities, and laboratory facilities. The study demonstrates that shortage of key elements is the main challenge of quality $\mathrm{HE}$ in public universities in Bangladesh. Budgetary provision and utilization of the same are two major limiting factors in improving those facilities. Alinoor and Muttakin (1999) identified that most of the government universities in Bangladesh are suffering from budget deficit; budgeting practices are in most cases traditional and no effort has yet been made to change these by the university authority or by the government. Sarkar, Hossain and Rahman (2014) observed that insufficient budget for education in Bangladesh has a negative impact on expansion of HE and improving the Human Development Index (HDI). Baldwin and McCracken (2013) investigated the validity of the claim that investing in HE will help restore state economic growth and prosperity in U.S. Ahmed, Farley and Naidoo (2012) stated that the intention of Malaysian government to implement the HE reforms is observable in the implementation of national HE plan beyond 2020 in 2007. As a result of this reform, public universities are required to generate their own finance in order to supplement the limited and insufficient funding from the federal government. They also mentioned that the use of performance based funding will be implemented to Malaysian public universities to stimulate them to be more competitive. Ponce and Loayza (2012) observed that eliminating tuition fees has no significant impact on opportunities for tertiary education. The empirical evidence showed that the policy of free tuition fees in public universities in Ecuador has non-progressive effects. Livanos (2010) observed that graduates of polytechnics and computer science discipline have high levels of private sector employment in the Greek labor market than graduates of social and humanities disciplines. The study results also revealed that individuals with postgraduate qualifications ( $\mathrm{PhD}$, Masters) have higher probabilities of looking for a longer period job than graduation only. The findings of this study stress the need for drastic reforms in HE. Núñez and Livanos (2010) examined the impact of an academic degree and field of study on short and long-term unemployment across Europe. Labor Force Survey (LFS) result indicates that an academic degree is more effective in reducing the likelihood of short-term than long-term unemployment. They also found that HE increases the chances of employment. Cosser (2010) investigated the relationship between grade 12 learners' preferences for study in $\mathrm{HE}$, student enrolment in HE program, and student graduations in different program areas, considering the match between these supply-side indicators and a forecast of skills demand in South Africa to ascertaining the extent to which the HE system is meeting the demand for skills in the labor market. Khan (2009) identified that high rate of unemployment, poverty; inequality and vulnerability are due to poor stock of human capital in most of the developing countries. Oketch (2003) opted that sluggish economic growth generates high level of 
graduate unemployment. Moreover, absence of career counseling at universities means students do not know what they want with any precision. Alam, Khalifa and Shahjamal (2009) assessed that investment in education provides a significant return; therefore, countries are paying especial priority in allocating budget. Islam (2008) recognized that there is demand for $\mathrm{HE}$ due to increase of enrolment in higher educational institutions, but enrollment pattern reflects interdisciplinary imbalance. The unemployment of huge products of education implies that HE is not effective and relevant for their absorption in appropriate jobs. So the present pattern of HE needs to be reformed through national planning, manpower requirements and educational application. Rizvi (2009) stated that Bangladesh as a developing county has been suffering from low investment in education particularly in research and development. Universities in Bangladesh are viewed mostly as teaching institutions with no prospect or incentives for research in one hand and in other hand lack of financial resources, libraries, laboratories and equipments, and failure to invest in them has contributed to diminishing research capabilities. Iqbal (2011) in Daily Prothom Alo mentioned that the public universities in Bangladesh are not giving importance on research work due to shortage of fund. Mehmood, Khan, Raziq, and Tahirkheli (2012) mentioned that research could increase the level of HE quality. Hasan (2013) in Daily Prothom Alo disclosed that due to session jam students and guardians' are financially victimized in one side, and in other side a big amount of social and state assets are misused. Rizvi, G. (2012) urged in Daily Prothom Alo that allocation for HE need to be considered as an investment instead of expenditure. Rao (2006) mentioned that HE contributes to national development through dissemination of specialized knowledge and skills. He also opined that education is universally recognized as an investment in HR. Saad and Kalakech (2009) identified that education is the key sector to which public expenditure should be directed to foster economic growth in the long-run.

A large amount of money may be spent in unproductive fields through designing less economically relevant courses and fields of studies in basic and HE (Farzanegan, 2011). HE consumes a large portion of public and private funds to ensure economic development, but due to job pattern in Bangladesh and requirements placed for recruitment, contribution from higher education is lower where investment per student is reasonably higher. According to their analysis, only 30 percent of science graduates, around 60 percent of professional graduates, and 70 percent of medical graduates are involved in respective professions and remaining portion are in different non related fields. They also identified that Medical graduates used maximum 40 percent of knowledge, and graduates from others fields used less than 40 percent of HE knowledge in their profession (Alam, Shahjamal, \& Roy, 2009). Expected goals and objectives of education in Bangladesh have been hindered due to existence of waste/ misuse in the education system. A large number of experienced persons are required for the business enterprises established in Bangladesh through foreign direct investment due to globalization. Waste of education can partially be eliminated through preparing our educated people considering the requirements of those enterprises (Islam \& Riad, 2008). Underemployment situation of the HE graduates in Bangladesh has been a serious problem. In today's fluctuating market, academic institutions should be kept under pressure to equip their students with those types of qualifications that are relevant and contain marketable skills. To reduce the graduate level unemployment rate in Bangladesh, the tertiary education establishments of this country should focus on developing curricula and teaching material, restructuring of education and assessment policy, modernization of infrastructure facilities, linkage program between education and society, co-opt scheme for industry, training institutions for faculty members at the tertiary level, etc (Chisty, Uddin, \& Ghosh, 2007). Lin and Hsu (2013) found that higher education can upgrade personal social status and income; it might lead to the wasting of educational and human resources when highly educated graduates cannot immediately find appropriate jobs. Shin (2012) opted that the growth of Korean $\mathrm{HE}$ is remarkable for its quality as well as quantity due to government policy initiatives to invest aggressively in research and development (R\&D). If this manpower is not placed in the right positions, $\mathrm{HE}$ functions will fail to give benefit to the society and economy. So it is urgently needed to develop HR giving emphasis on both local and global perspectives as well as ensuring proper placement of those graduates.

After review of literature it is found that some research works have been done in the field of HE giving emphasize on quality, HRD, economic development, budgetary control practices, budgetary allocation and organizational characteristics, return on investment on education, education spending and productivity, efficiency and waste in education, employability of graduates, unemployment of HE graduates, etc. Most of the studies mentioned about inadequacy of fund for HE in South Asian countries especially in Bangladesh. But no in-depth study has yet been conducted using field level data to find out productive or unproductive utilization of HE budget in Bangladesh. That's why the present study is an attempt to fill this gap and the study will contribute to the existing stock of knowledge.

\section{Methodology}

The study was based on both primary and secondary sources of data. Primary data was collected from 557 alumnae of the public universities who were in the jobs required non-technical educational entry qualification and 63 faculties from four categories of universities. The population of the study was divided into two categories, specifically faculties of the public universities, and alumnae of the public universities who were in the jobs 
required non-technical ${ }^{1}$ educational entry qualification. To collect primary data from alumnae, participants were selected from different training programs organized and managed by the training institute in Bangladesh. The researcher randomly selected a good number of training batches considering the convenience of time and availability, and data was collected from all the participants of the selected batches with unofficial support from the executives of those training institutes. The trainees of the individual training program were selected by the training institute.

A multi-stage sampling procedure was followed to draw the sample of the study. The sample size was limited to 620 respondents from two strata. The sample from each stratum is shown as follows-

\begin{tabular}{|l|l|l|l|l|}
\hline Strata & Strata Group & Population & Sampling Techniques & Sample \\
\hline Strata-1 & Academician & 9,962 & Best judgment from each strata ${ }^{2}$ & 63 \\
\hline Strata-2 & Alumnae & $\begin{array}{l}\text { Graduates from } \\
\text { public universities } \\
\text { (Number } \\
\text { unknown) }\end{array}$ & $\begin{array}{l}\text { Data was collected from the alumnae at the time of their } \\
\text { training at Bangladesh Public Administration Training } \\
\text { Centre, Regional Public Administration Training Centre } \\
\text { (Rajshahi), different training institutes of Banks. }\end{array}$ & 557 \\
\hline Total & & & $\mathbf{6 2 0}$ \\
\hline
\end{tabular}

However, secondary data for the study was collected from the annual reports of the University Grants Commission (UGC) of Bangladesh during the period 2000 to 2012, different publications of UGC, different publications of Bangladesh Bureau of Education Information and Statistics (BANBEIS), different publications of Bangladesh Bureau of Statistics (BBS), different publications by the GOB such as education commission reports, five years plans, annual reports of PSC in Bangladesh, Bangladesh Bank publications, UNESCO publications on education budget, human development reports published by UNDP, books and journal articles, print media, related websites, etc.

The data processing activities consisted of editing, coding, data entry, checking consistency, summarizing, classifying, etc. It should be mentioned here that all monetary value was converted into current value of money. Current value was calculated based on consumer price index (CPI) of Bangladesh Bureau of Statistics (BBS). All the nominal value of Taka was converted into current value of 2012-13 (current year) based on Index value Base: 1995-96=100 (general). Index factor was calculated by:

$\mathrm{I}_{\mathrm{f}}=\mathrm{CPI}_{\mathrm{c}} / \mathrm{CPI}_{\mathrm{r}}$

Here, $\mathrm{I}_{\mathrm{f}}$ indicates calculated index factor, $\mathrm{CPI}_{\mathrm{c}}$ indicates $\mathrm{CPI}$ of current year, $\mathrm{CPI}_{\mathrm{r}}$ indicates $\mathrm{CPI}$ of respective year.

The researcher used Winsorized mean ${ }^{4}$ to calculate the average monthly expenses by students in their university life. In the calculation the researcher repaired 10 percent of extreme higher value under the method of Winsorized mean.

\footnotetext{
${ }^{1}$ Open to apply from all disciplines of study. A candidate has graduation and post graduation degrees or only graduation from any discipline of a university is eligible to apply.

2 Academicians include researchers and faculties of public universities. Total number of faculties in public universities were 9,962 (excluding part-time faculties) in 2011 (UGC, 2011, p.128). Faculties of four categories- general, agricultural; engineering and science \& technology universities- were purposively selected. Finally faculties were selected randomly on the basis of availability and their willingness to provide information. About 140 faculties were selected as respondents and distributed questionnaire among them. Out of them 63 respondents returned the questionnaire with their valuable opinions.

${ }^{3}$ Total 1050 questionnaires were distributed among the alumnae participated in different training programs. Out of them 839 respondents returned the questionnaire with their valuable opinions. The researcher excluded 282 filled up questionnaire of the respondents who had graduation from National University, Bangladesh Open University, private universities and employed in technical job. Responses of 557 respondents were selected as valid response because all of the respondents completed their higher education from public universities and employed in non-technical job.

4 A method of averaging that initially replaces the smallest and largest values with the observations closest to them. After replacing the values, a simple arithmetic averaging formula is used to calculate the Winsorized mean. Winsorized mean is less sensitive to outliers because it replaces them with less influential values. This method of averaging is similar to the trimmed mean; however, instead of eliminating data, observations are altered, allowing for a degree of influence.
}

(Source: http://www.investopedia.com/terms/w/winsorized_mean.asp date: 22.04.2014) 
After the completion of data processing, the researcher turned his attention to analyze both quantitative and qualitative data. The data were analyzed by using Statistical Package for Social Science (SPSS) version 15 and Microsoft Excel. In course of descriptive analysis, frequency, mean, percentile was adopted. Some diagrams and charts were also developed to have easy understanding of different issues.

\subsection{Unemployed Higher Educated People in Bangladesh}

\section{Result and Discussion}

Unemployment is a serious problem in Bangladesh. According to the Labor Force Survey (2010), out of 2,568 thousand unemployed person, 642 thousand have no education, 1,820 thousand have education up to Higher Secondary (12 years education) or equivalent level, 105 thousand have under-graduation and above, and 1 thousand in other category. The government and the guardians spent a huge amount of money to educate those 105 thousand people. Due to unemployment, total investment of the government and the graduates themselves or their guardians could be considered as idle investment from the economic point of view.

\subsubsection{Financial Burden of Unemployed Higher Educated People}

Government and guardians of the unemployed higher educated people have been spending a huge amount of money to educate the unemployed graduates.Table-A.1 (in Appendix) shows the short-term unemployment period of the graduates from different categories of universities. The short term unemployed period of the students of general universities was 10.01 months, agricultural universities was 9.42 months, engineering universities was 7.29 months and science \& technology universities was 9.40 months before getting their first job. Consequently, guardians had to spend on an average BDT 68,838 to BDT 84,384 per year for each student and the government had to spend BDT 49,320 to BDT 170,988 per student in different categories of universities. Per student expenditure according to university schedule time (normal required time) in general university was BDT 604,220, engineering university was BDT 737,253, science \& Technology University was BDT 647,753, and in agricultural university was BDT 1,317,044. Owing to unemployment problem, total investment of the government and guardians was idle investment for the period of unemployment. Similarly, investment for lifelong unemployed people is totally an idle investment.

\subsubsection{Proposal for Reducing Unemployed Higher Educated People}

It is evident from table-A.2 (in Appendix) that 61.9 percent of faculties under the study suggested the need for reducing the lengthy system of recruitment through providing all government jobs on the basis of merit and choice from one examination for jobs (36.5 percent) and arrangement of job fair (34.9 percent). Importance should be given on merit (65.1 percent) only and gradually reduces quota system (68.3 percent) for providing job. They also gave emphasis on (41.3 percent) reducing unemployment at zero level.

\subsection{Impact of Session Jam}

Session jam in public universities in Bangladesh is a matter of discussion and debate in public gathering as well as in different seminars and symposium on HE. It disrupts the academic life of the university students. The lengths of academic life of the students beyond schedule session consume extra resources of their parents and the academic institutions. Running of many sessions simultaneously put huge stress on the administration, management and facilities of higher academic institutions which ultimately affects the quality of HE and community life of the students (Islam, 2012, p.81). Academic session in some public universities of Bangladesh is delayed badly and as such students and their guardians' are compelled to bear the financial and nonfinancial losses in one side and a huge amount of social and state assets is misused in other side. Consequently, the national goal of HRD is seriously disrupted (UGC 2011, p.216). In reality there are triangular losses due to session jam. Government has to spend additional money, parents have to bear extra financial burden and students are to lose time to get jobs during the delayed period due to session jam. They could get employment earlier if there is no session jam. Thus the government has failed to utilize human resources properly in the economic development of the country.

\subsubsection{Duration of Session Jam}

It is evident from table-A.1 (in Appendix) that session jam was responsible for loss of several student months from their academic life. The periods of session jam were different in different categories of universities. The average duration, based on primary data, was higher in general universities (20.65 months) and lower in agricultural universities (10.6 months). Figure-1 visualize common scenario of average session jam in different categories of public universities. It should be mentioned here that the duration of session jam was varied among different categories of universities as well as different time periods. 
Figure-1 Per Student Mean Session Jam in Different Categories of Universities (in Months)

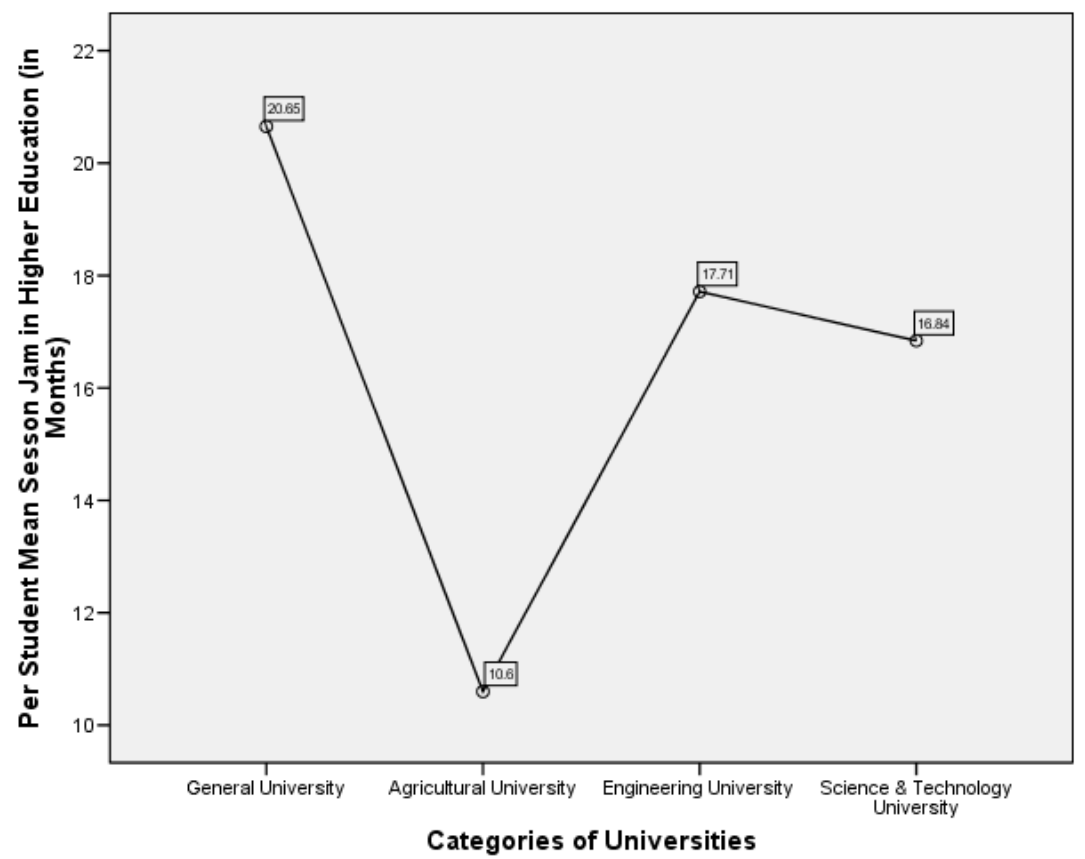

Source: Self constructed using primary data.

\subsubsection{Financial Consequences of Session Jam}

It is evident from table-A.1 (in Appendix) that due to session jam a big amount of money is spent both by the guardian and the government for a student to complete his/her graduation and post graduation. It is found from the statistical computation that per student extra expense was highest (BDT 230,801) in engineering universities, followed by agricultural universities (BDT 211,846), general universities (BDT 209,794), and science \& technology universities (BDT 179,293) in that order. In relative term general universities consumed 25.77 percent, agricultural universities consumed 13.86 percent, engineering universities consumed 23.84 percent and science $\&$ technology universities consumed 21.68 percent additional expenses due to session jam.

Figure-2 Per Student Expenses in University (by Government and by Guardian) at Current Value of Bangladesh Taka

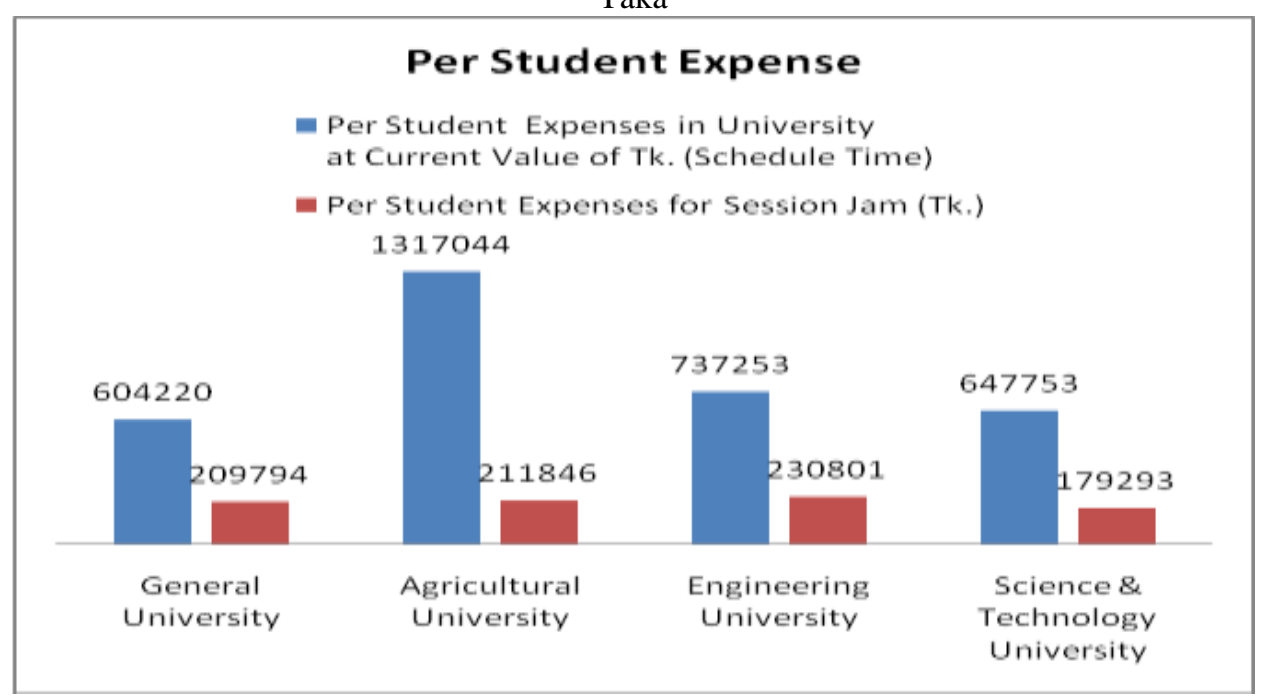

Source: Self constructed from source table-A.1 in appendix.

\subsubsection{Financial Pressure on Government due to Session Jam}

It is evident from table-A.1 (in Appendix) that the public universities in Bangladesh have been spending a big amount of extra money for their students due to session jam. Session jam was not equal in all categories of universities and within a particular category of universities. Extra expenditure by the government 
was also varying in different categories of universities. Statistical results reveal that the government had to spend on an average BDT 939,009 per student of agricultural universities in schedule time and total BDT $1,090,048$ to complete his/her university education with extra time due session jam. Thus the additional amount spent per student due to session jam was BDT 151,039 (0.16 times of the scheduled expenses). The government spent a big amount of extra money per student of general universities ( 0.35 times of the schedule expenses), engineering universities ( 0.31 times of the schedule expenses) and ( 0.28 times of the schedule expenses) science \& technology universities (Figure-3), but the amount in absolute term was far less than the agricultural universities.

Figure-3 Per Student Government Expenses at Current Value of Bangladesh Taka

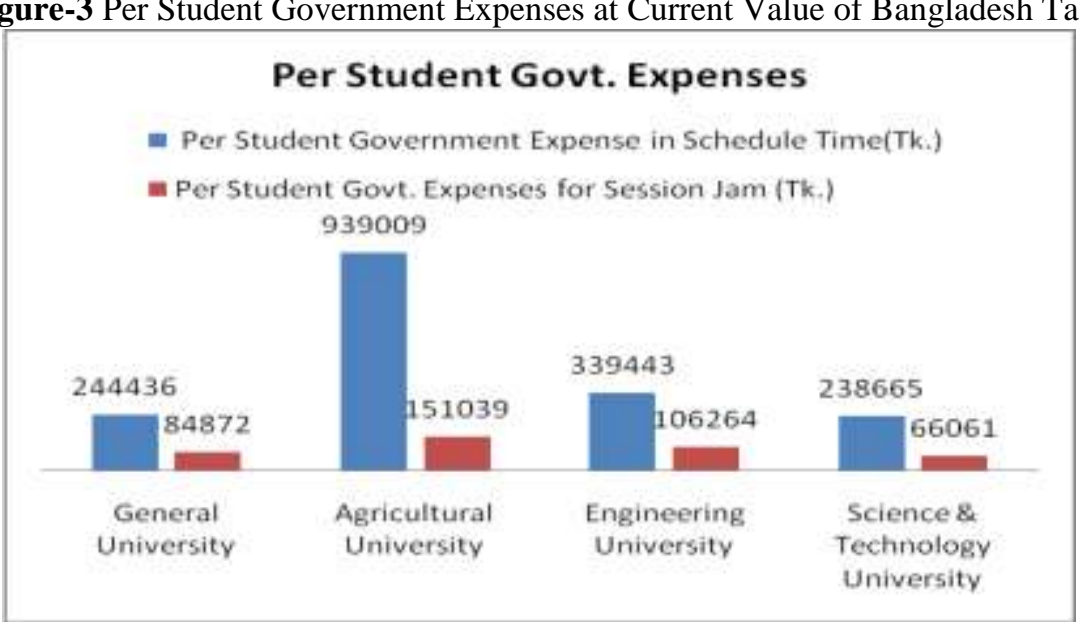

Source: Self constructed from source table-A.1 in appendix

\subsubsection{Financial Pressure on Guardians}

It is evident from table-A.1 (in Appendix) that all students of public universities in Bangladesh need to spend extra money due to session jam. Extra expenditure by the students and or their guardians is also varied in different categories of universities. It is found from statistical results that on an average every student of general universities had to spend an extra amount of BDT 124,922 and engineering universities BDT 124,537 in their graduation or graduation with post graduation level. Students of others categories of universities also had to spend a big amount of extra money due to session jam, but the amount was less than that of the general universities and engineering universities (Figure-4).

Figure-4 Per Student Expenses of the Guardians at Current Value of Bangladesh Taka

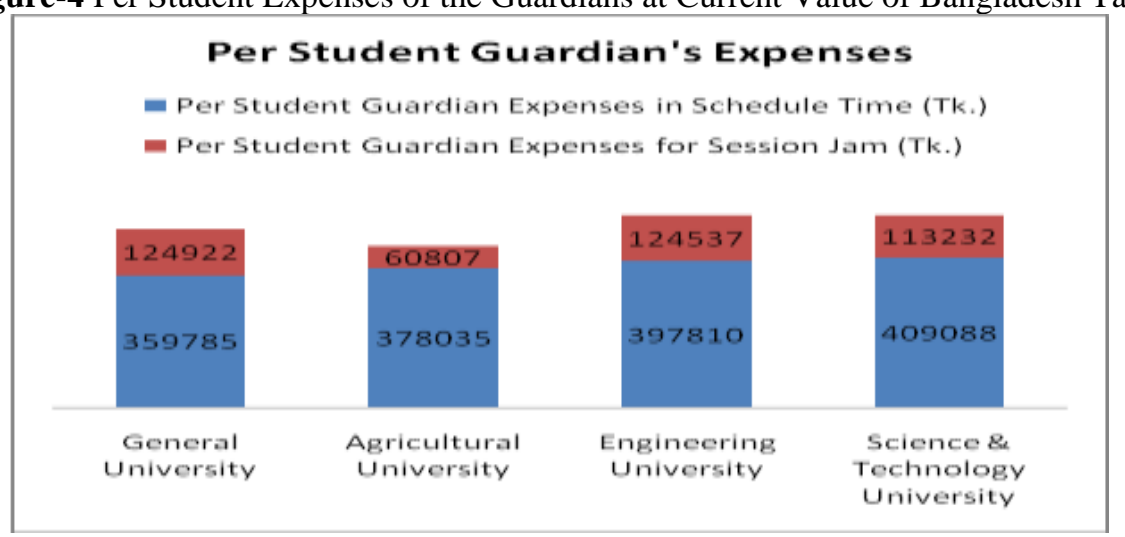

Source: Self constructed from source table-A.1 in appendix

\subsubsection{Opinion Survey on Consequences of Session Jam}

It is evident from table-A.3 (in Appendix) that there are financial and non-financial consequences of session jam. About 62 percent faculties of the study sample agreed that extra expense of government was misused due to session jam. Similarly, about 59 percent faculties opined that extra expense of guardians was misused and about 56 percent alleged that the students had to lose their earnings opportunities due to unusual delay in starting their working life. Concomitantly, about 64 percent of the faculties thought that delayed in working life was the outcome of session jam which might have slowed down the economic development of the country. 


\subsection{Impact of Employment Nature}

It is evident from literature and Table-A.4 (in Appendix) that the return from HE is not satisfactory due to high unemployment and job nature. Most of the employments are not related to HE discipline. Many Civil Engineers, Bachelor of Medicine and Bachelor of Surgery (MBBS) Doctors, Veterinary Doctor are not placed in their area of expertise and specialized fields. They get job in foreign affairs, police, administration, and customs which could be performed by the non-technical graduates, but it is not possible to serve technical fields by nontechnical graduates. Graduates from the discipline of genetic engineering, computer engineering, micro biology, chemistry are also opted for jobs in administration, police, customs, and foreign affairs. Contrarily, graduates from international relations hardly get job in foreign affairs and students of public administration are getting job in foreign affairs. It is one kind of unproductive and improper utilization of public as well as private funds and expertise.

\subsubsection{Financial Involvement due to Employment Nature}

Table-A.5 (in Appendix) discloses that around 13.6 percent of non-technical job was occupied by the graduates in the field of agriculture including Veterinary Doctors and 7.7 percent of non-technical job was occupied by highly technical engineering graduates. It should be mentioned here that per student yearly expenditure at agricultural universities was around 3.5 times higher than general, and science \& technology universities. When an agricultural graduate joins in a non-technical job then around 88 (Table-A.1 in Appendix) percent of expenses for that graduate from government fund should be treated as unproductive expenses because the objective of producing technical graduates is to utilize their expertise in their field of specialization.

\subsubsection{Opinion Survey on Employment Nature}

It is evident from table-1 that the mean score of opinions of the alumnae regarding 'technical graduates should be employed in their own field of specialization' was 4.54 in the scale of 5.00 and mode was 5.00. Figure 5 depicts the alumnae opinions on agree with the statement.

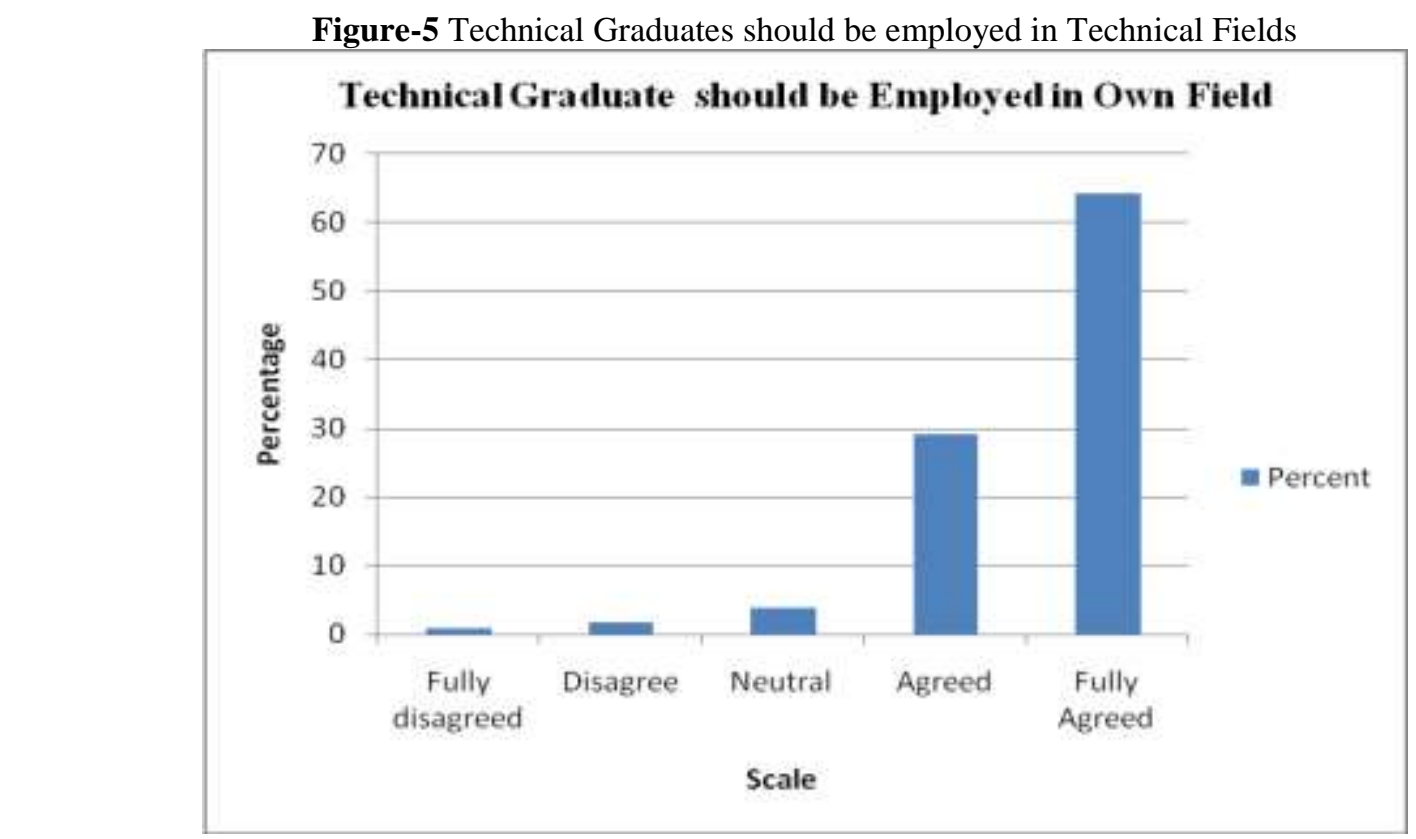

Source: Self constructed using primary data collected through questionnaire from alumnae

Most (90.5 percent) of the faculties (Table-1) in the study sample agreed that the technical graduates (doctor, engineer, agronomist, etc.) should be employed in their own field of specialization. Figure 6 shows the opinions of the faculties on the statement. 
Figure-6 Technical Graduates should be employed in Technical Fields

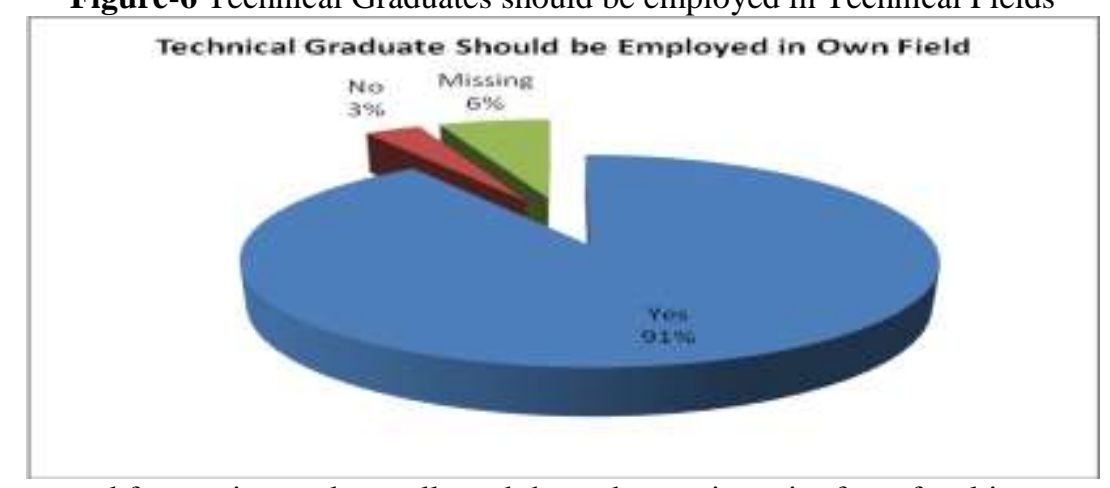

Source: Self constructed from primary data collected through questionnaire from faculties

Similarly, 60.0 percent of the faculties under the study believed that employee productivity would have been increased if the technical graduates were employed in their study area (Table-A.2 in Appendix).

Table-1 Technical Graduates should be employed in their Own Field of Study

\begin{tabular}{|l|l|l|l|l|}
\hline Alumnae Opinion & Faculties' Opinion & Frequency & Percentage \\
\hline Statistics & Value & Opinion & 57 & 90.5 \\
\hline Mean & 4.54 & Yes & 2 & 3.2 \\
\hline Mode & 5.00 & No & 4 & 6.3 \\
\hline & & No Comment & 54 & 100 \\
\hline Total Frequency & 557 & Total & 54 \\
\hline
\end{tabular}

Source: Analysis of primary data collected through questionnaire from alumnae and faculties

It is evident from table-A.3 (in Appendix) that 46 percent of the faculties under the study agreed that extra investment for technical graduates employed in non-technical jobs is unproductive. They also opined that (Table-A.3 in Appendix) the productivity of a technical graduate is reduced (42.9 percent) when s/he works in a non-technical field.

\subsubsection{Proposal for Employment of Higher Educated People}

It is evident from table-A.2 (in Appendix) that 52.4 percent of the faculties under the study felt that new intake in discipline of higher education should be based on the scope of potential job opportunities in a particular field. To create awareness, 31.7 percent of them believed that counseling system should be introduced in Higher Secondary level for higher education and future employment. Similarly, 69.8 percent proposed to include the importance of self employment in course curricula to motivate higher educated people for self employment (68.3 percent).

\section{Conclusions}

The purpose of higher education is to transform a country's population into skilled manpower. The valid ground for this objective is that the skilled manpower should be employed in their own field of study to reap maximum benefits from their expertise and specialized knowledge. In order to attain the goal of higher education, different fields of study such as medical, engineering, agricultural, science, business, law, etc. should be offered by the educational institutions keeping an eye on the needs of the national and international job market. Government has been investing a huge amount of money since the independence of Bangladesh to transform the population into human assets in order to achieve maximum productivity of physical and nonphysical assets. But in reality the objective has not yet been achieved due to short-term and long-term unemployment of higher education graduates, session jam, and employment alien to their field of expertise. Unemployment is a common phenomenon in Bangladesh. A large part of higher education budget is inoperative due to short-term and long-term unemployment, and consequently, Bangladesh is deprived of getting the services of unemployed higher educated people. On the other hand session jam consumes 11 to 21 months additional time than the schedule time of HE graduates varied among categories of universities and different time periods. There are multidimensional losses such as government and guardians ought to bear an extra pressure of expenditure and students ought to lose potential earnings and are delayed to start their working life; ultimately the country is deprived of getting the services from those graduates for the period of session jam. Job nature has also a negative impact on utilization of budget. Technical graduates are produced with the goal of getting the services in their areas of specialization, but due to the requirements in recruitment and defective selection process, a huge number of technical graduates are absorbed in non technical jobs. Technical graduates consume 3 to 5 times' higher budget than general graduates. When technical graduates are employed in non- 
technical field around 40 to 45 percent of their HE expense should be treated as unproductive because productivity of technical graduates is not utilized properly.

In the above context, more attention should be given to enhance the rate of productive utilization of higher education budget through different initiatives such as minimizing session jam at zero level through stringent use of academic calendar and make the educational institutions free from internal and external politics and poor academic culture. The rate of unemployment can be reduced to zero level through creating more job opportunities both in public and private sectors and encouraging self employment as well as reducing the timespan of the recruitment process. In order to minimize the mismatch between technical skills and job nature, different initiatives should be taken from different sectors. The government should formulate short-term and long-term manpower planning considering the future manpower needs in different fields of expertise in light of employment opportunities at home and in abroad.

\section{References}

[1]. Adawo, M. A. (2011). Has education (human capital) contributed to the economic growth of Nigeria?. Journal of Economics and International Finance, 3(1), 46-58. Retrieved from

[2]. Ahmed, A. R., Farley, A., \& Naidoo, M. (2012). Impact of the government funding reforms on the teaching and learning of Malaysian public universities. Higher Education Studies, 2(2), 114-124. Doi:10.5539/hes.v2n2p114

[3]. Alam, G. M., Khalifa, M. T. B., \& Shahjamal, M. M. (2009). Return from education system in Bangladesh: an investigation on comparative flashback scenario. African Journal of Business and Management, 3(10), 567-575. Retrieved from http://www.academicjoumals.org/ajbm/pdf/pdf2009/oct/alam\%20et\%20al..pdf

[4]. Alam, G. M., Shahjamal, M. M., and Roy, G. (2009). Rate of return of education in Bangladesh: An investigation. Teacher's World, 33-34, 73-86.

[5]. Alinoor, M. \& Muttakin, M. B. (1999). Budgetary control practice of Islamic University: A case study. Islamic University Studies, 2(2), 133-146.

[6]. Baldwin, J. N., \& McCracken, W. A. (2013). Justifying the ivory tower: Higher education and state economic growth. Journal of Education Finance, 38(3), 181-209. Retrieved from http://muse.jhu.edu/journals/journal_of_education_finance/toc/jef.38.3.html

[7]. Bangladesh Bureau of Education Information and Statistics (BANBEIS). (2011). Bangladesh Education Statistics 2010. Publication No. 404, Government of the Peoples Republic of Bangladesh, 214-216.

[8]. Bangladesh Bureau of Education Information and Statistics (BANBEIS). (2001.). Statistical Profile on Education in Bangladesh2001. Publication No, 350, Government of the Peoples Republic of Bangladesh, Dhaka.

[9]. Bangladesh Bureau of Education Information and Statistics (BANBEIS). (2012). Pocket Book on Education Statistics-2011. Publication No. 416, Government of the People's Republic of Bangladesh, Dhaka.

[10]. Bangladesh Bureau of Statistics (BBS). (2011). Statistical Pocketbook Bangladesh 2010. Government of the Peoples Republic of Bangladesh, Dhaka.

[11]. Bangladesh Bureau of Statistics (BBS). (2012). Consumer Price Index (CPI) Bangladesh, Issue No. 211. National Accounting Wing, Government of the People's Republic of Bangladesh, Dhaka.

[12]. Bhatia, K. \& Dash, M. K. (2010). A comparative analysis of higher education system of India with other countries. American Journal of Scientific Research, 12, 137-152. Retrieved from http://www.eurojournals.com/ajsr_12_12.pdf

[13]. Bhuiyan, B. A., Ahmmed, K., \& Molla, M. S. (2009). A theoretical framework for quality assurance in higher education in Bangladesh. Journal of Business, Society and Science. 1(1), 27-51.

[14]. Chaudhary, A. R., Iqbal A., \& Gillani, S. Y. M. (2009). The nexus between higher education and economic growth: An empirical investigation for Pakistan. Pakistan Journal of Commerce and Social Sciences, 3, 01-09.

[15]. Chauhan, C. P. S. (2008). Higher education: Current status and future possibilities in Afghanistan, Bangladesh, Bhutan, India, Maldives, Nepal, Pakistan, and Sri Lanka. Analytical Reports in International Education, 2(1), 29-48. Retrieved from http://aried.info/00ISSUES/BACK/2008/0201-arch2008/PDF/Ch2-Chauhan-29-48.pdf

[16]. Chisty, K. K. S., Uddin, G. M., \& Ghosh, S. K. (2007). The business graduate employability in Bangladesh: Dilemma and expected skills by corporate world. BRAC University Journal, 4(1), 1-8.

[17]. Cosser, M. (2010). The skills cline: higher education and the supply-demand complex in South African. Higher Education, 59(1), 43-53. DOI: 10.1007/s10734-009-9231-z.

[18]. Farzanegan, M. R. (2011). Education spending and productivity in Iran: where have all the education expenditures gone? Politics and Economic Development, ERF 1 $7^{\text {th }}$ Annual Conference, 1-16. Retrieved from http://tudresden.de/wwvwlfw/team_mitarbeiter_mohammad_e.htm

[19]. Government of Bangladesh (GOB). (2010), National Education Policy 2010, (Dhaka: Bangladesh Government Press).

[20]. Government of the People's Republic of Bangladesh (GOB). (2002). Report of Education Adornment Specialist Committee. Ministry of Education, Dhaka.

[21]. Hasan, S. (2013). To honorable vice-chancellors. Prothom Alo, 16.01.2013. Retrieved from http://eprothomalo.com/displaypage. php?id=2013_01_16_10_1_b

[22]. Heckman, J. J. (2005). China's human capital investment. China Economic Review, 16, 50-70. Retrieved from http://jenni.uchicago.edu/Papers/Heckman_ChinaEconRev_v16_2005.pdf

[23]. Iqbal, M. Z. (2011). Only one thousand PhD. Prothom Alo, p.12, 6 June 2011.

[24]. Islam, F. (2008). Some issues of higher education in Bangladesh: analysis of demand, problems and trends. Prime University Journal, 2(2), $137-152$.

[25]. Islam, F. (2012). Higher education in Bangladesh: Prospects and challenges ( $1^{\text {st }}$ ed.). Dhaka, Bangladesh: Desh Publications Ltd.

[26]. Islam, F., \& Riad, S. S. (2008). Education efficiency and wastage: Bangladesh perspective. Bangladesh Unnion Sommikkah, 25, 99-112.

[27]. Khan, M. A. (2009). Human recource [sic] development and financing issues: A South Asian perspective. SAARC Journal, 5(1), 117.

[28]. Khatun, S. (2003). Access to education: an inquiry into the present situation in Bangladesh. Journal of the Asiatic Society of Bangladesh Humanities, 48(2), 37-57. 
[29]. Lin, Y. L., \& Hsu, C. J. (2013). The effects of over-education on unemployment duration: evidence from Taiwan. Journal of Emerging Issues in Economics, Finance and Banking, 1(5), 430-443. Retrieved from http://www.globalbizresearch.com/images/files/16129_JEIEFB_Yen-Ling\%20Lin\%20\&\%20Chi-Jung\%20Hsu.pdf

[30]. Livanos, I. (2010). The relationship between higher education and labour market in Greece: the weakest link? Higher Education, 60(5), 473-489. doi:10.1007/s10734-010-9310-1.

[31]. Mehmood, I., Khan, S. B., Raziq, K. \& Tahirkheli, S. A. (2012). Role of academic leadership in change management for quality in higher education in Pakistan. Journal of Education and Practice, 3(16), 194-198. Retrieved from http://www.iiste.org/Journals/index.php/JEP/article/view/3715/3764

[32]. Moak, M. M. (2009). Review of higher learning, greater good: the private and social benefits of higher education, 2009 (review). Journal of Education Finance, 35(2), 194-198. DOI: 10.1353/jef.0.0011

[33]. Núñez, I., \& Livanos, I. (2010). Higher education and unemployment in Europe: an analysis of the academic subject and national effects. Higher Education, 59(4), 475-487. DOI: 10.1007/s10734-009-9260-7

[34]. Oketch, M. O. (2003). Market model of financing higher education in Sub-Saharan Africa: examples from Kenya, Higher Education Policy, 16, 313-332

[35]. Ponce, J., \& Loayza, Y. (2012). Elimination of user-fees in tertiary education: A distributive analysis for Ecuador. International Journal of Higher Education, 1(1), 138-147. doi: 10.5430/ijhe.v1n1p138

[36]. Prothom Alo (24.01.2012). Retrieved from http://eprothomalo.com/displaypage.php?id=2-2_01_24_3_0_b

[37]. Rao, D. P. (2006). Genesis and growth of higher education in India. Journal of social and economic studies. 18 (1), 19-28.

[38]. Rizvi, G. (2009). Reinvesting Universities: Higher Education in a Global Society. Journal of the Asiatic Society of Bangladesh (Hum.), 54(2), 37-70.

[39]. Rizvi, G. (2012) in Prothom Alo. Retrieved from http://eprothomalo.com/displaypage.php?id=2-2_01_24_3_0_b

[40]. Saad, W., \& Kalakech, K. (2009). The nature of government expenditure and its impact on sustainable economic growth. Middle Eastern Finance and Economics, 4, 38-47. Retrieved from http://www.eurojournals.com/mefe_4_03.pdf

[41]. Sarkar, S. H., Hossain, S. Z. and Rahman, R. A. (2014).Budgetary provision for higher education: evidence from Bangladesh. Journal of Public Budgeting, Accounting and Financial Management, 26 (4), 643-671.

[42]. Sarkar, S. H., Rana, S. and Zitu, R. A. (2013). Challenges of quality higher education in Bangladesh: A study on public universities. Journal of Education and Practice, 4(8), 151-160.

[43]. Shin, J. C. (2012). Higher education development in Korea: western university ideas, Confucian tradition, and economic development. Higher Education, 46(1), 59-72. Doi: 10.1007/s10734-011-9480-5.

[44]. University Grants Commission of Bangladesh UGC. (2006). Strategic plan for higher education in Bangladesh: 2006-2026, Dhaka Bangladesh.

[45]. University Grants Commission of Bangladesh (UGC). (2010). Annual Report. Dhaka, Bangladesh.

[46]. University Grants Commission of Bangladesh (UGC). (2011). Annual Report. Dhaka, Bangladesh.

[47]. University Grants Commission of Bangladesh (UGC). Annual Report. 2001 to 2009, Dhaka, Bangladesh.

[48]. Welsch, G. A., Hilton, R. W., \& Gordon, P. N. (1992). Budgeting: Profit planning and control (Fifth Edition). Prentice-Hall of India Private Limited, New Delhi.

\section{Appendix}

Table-A.1 Information Regarding Unemployment, Session Jam and Job Nature

\begin{tabular}{|c|c|c|c|c|}
\hline \multirow[b]{2}{*}{ Particulars } & \multicolumn{4}{|c|}{ Categories of Universities } \\
\hline & $\begin{array}{l}\bar{\pi} \\
\overline{0} \\
\overline{0}\end{array}$ & 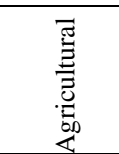 & 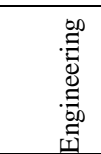 & 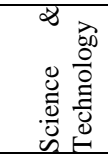 \\
\hline & Mean & Mean & Mean & Mean \\
\hline 1. Duration of university degree (in Year) & 4.96 & 5.49 & 4.71 & 5.07 \\
\hline 2. Duration of short-term unemployment (in Months) & 10.01 & 9.42 & 7.29 & 9.40 \\
\hline 3. Duration of session jam (in Months) & 20.65 & 10.6 & 17.71 & 16.84 \\
\hline 4. Per student per year government expense (BDT) & 49320 & 170988 & 72003 & 47074 \\
\hline 5. Per student per year guardian expenses (BDT) & 72594 & 68838 & 84384 & 80688 \\
\hline 6. Per student government expense in schedule time(BDT) $(1 \times 4)$ & 244436 & 939009 & 339443 & 238665 \\
\hline 7. Per student govt. expenses for session jam (BDT) $\{(3 \times 4) / 12\}$ & 84872 & 151039 & 106264 & 66061 \\
\hline 8. Per student govt. expenses for schedule time \& session jam (BDT) (6+7) & 329307 & 1090049 & 445707 & 304726 \\
\hline 9. Per student guardian expenses in schedule time (BDT) $(1 \times 5)$ & 359785 & 378035 & 397810 & 409088 \\
\hline 10. Per student guardian expenses for session jam (BDT) $\{(3 \times 5) / 12\}$ & 124922 & 60807 & 124537 & 113232 \\
\hline $\begin{array}{l}\text { 11. Per student guardian expenses for schedule time } \& \text { session jam } \\
\text { (BDT) }(9+10)\end{array}$ & 484707 & 438842 & 522347 & 522320 \\
\hline 12. Per student total expenses in schedule time (BDT) $(6+9)$ & 604220 & 1317044 & 737253 & 647753 \\
\hline 13. Per student total expenses for session jam (BDT) $(7+10)$ & 209794 & 211846 & 230801 & 179293 \\
\hline 14. Per student total expenses (govt.+ guardian) (BDT) $(12+13)$ & 814014 & 1528891 & 968054 & 827046 \\
\hline $\begin{array}{l}\text { 15. Govt. expenses for session jam as percent of govt. total } \\
\text { expenses }(\%)\{(7 / 8) \times 100\}\end{array}$ & 25.77 & 13.86 & 23.84 & 21.68 \\
\hline $\begin{array}{l}\text { 16. Guardian expenses for session jam as percent of total guardian } \\
\text { ex. }(\%)\{(10 / 11) \times 100\}\end{array}$ & 25.77 & 13.86 & 23.84 & 21.68 \\
\hline $\begin{array}{l}\text { 17. Expense for session jam as percentage of total expenses } \\
(\%)\{(13 / 14) \times 100\}\end{array}$ & 25.77 & 13.86 & 23.84 & 21.68 \\
\hline $\begin{array}{l}\text { 18. Per student extra expenses in general universities (including } \\
\text { session jam) due to job nature (BDT) }\end{array}$ & 0 & 714877 & 154040 & 13032 \\
\hline $\begin{array}{l}\text { 19. Per student extra expenses in general universities (including } \\
\text { session jam) due to job nature (\%) }\end{array}$ & 0 & 87.82 & 18.92 & 1.60 \\
\hline 20. Per student extra expenses in general universities (excluding & 0 & 712824 & 133033 & 43533 \\
\hline
\end{tabular}




\begin{tabular}{|l|l|l|l|l|}
\hline session jam) due to job nature (BDT) & & & \\
\hline $\begin{array}{l}\text { 21. Per student extra expenses in general universities (excluding } \\
\text { session jam) due to job nature (\%) }\end{array}$ & 0 & 54.12 & 22.017 & 7.20 \\
\hline
\end{tabular}

Source: Self calculated based on both primary and secondary data

Table-A.2: Employment of Higher Education Graduates in Bangladesh

\begin{tabular}{|l|l|l|l|}
\hline SI No & Particulars & Frequ-ency & Percent-age \\
\hline 1 & $\begin{array}{l}\text { Seat capacity of higher education institutions should be determined considering the } \\
\text { scope of jobs }\end{array}$ & 33 & 52.4 \\
\hline 2 & $\begin{array}{l}\text { Arrange counseling of higher secondary students for their higher education and } \\
\text { employment }\end{array}$ & 20 & 31.7 \\
\hline 3 & Productivity will increase if the technical graduates are employed in their study area & 38 & 60.0 \\
\hline 4 & Strive to reduce unemployment rate at zero level & 26 & 41.3 \\
\hline 5 & Give importance only on merit for job employment & 41 & 65.1 \\
\hline 6 & Recruitment based on quota system should be reduced gradually & 43 & 68.3 \\
\hline 7 & Reduce the length of the recruitment process & 39 & 61.9 \\
\hline 8 & $\begin{array}{l}\text { Provide all govt. jobs through only one examination considering qualities and } \\
\text { choices of the candidates }\end{array}$ & 23 & 36.5 \\
\hline 9 & $\begin{array}{l}\text { Arrange job fairs for providing jobs } \\
\text { An }\end{array}$ & 22 \\
\hline
\end{tabular}

Source: Analysis of primary data collected from faculties of public universities through semi-structured questionnaire

Table-A.3: Utilization of Higher Education Budget in Bangladesh

\begin{tabular}{|l|l|l|l|}
\hline Sl. No. & Particular & Frequ-ency & Percen-tage \\
\hline 1 & Per student extra expenditure of the government due to session jam is a waste & 39 & 61.9 \\
\hline 2 & Additional expenditure of guardians due to session jam is a waste & 37 & 58.7 \\
\hline 3 & $\begin{array}{l}\text { Loss of earning opportunity of students due to delay in starting working life for } \\
\text { session jam }\end{array}$ & 35 & 55.6 \\
\hline 4 & $\begin{array}{l}\text { Delay in contributing to the economic development of the country due to delay in } \\
\text { starting working life for session jam }\end{array}$ & 40 & 63.5 \\
\hline 5 & $\begin{array}{l}\text { Extra expense (expenses of technical graduate minus expenses of general } \\
\text { graduate) for technical graduates working in non-technical jobs is unproductive }\end{array}$ & 29 & 46 \\
\hline 6 & $\begin{array}{l}\text { Productivity of technical graduates (agriculture, medical, engineer, etc.) is } \\
\text { reduced when they work in non-technical (police, admin, banker, etc.) field }\end{array}$ & 27 & 42.9 \\
\hline
\end{tabular}

Source: Analysis of primary data collected from faculties of public universities through semi-structured questionnaire

Tabe-A.4: Cadre Distribution in BCS Examination and Field of Higher Education

\begin{tabular}{|c|c|c|c|c|c|c|c|c|}
\hline \multirow{2}{*}{$\begin{array}{l}\text { Merit } \\
\text { Position }\end{array}$} & \multicolumn{2}{|l|}{$28^{\text {th }}$ BCS } & \multicolumn{2}{|l|}{$29^{\text {th }}$ BCS } & \multicolumn{2}{|l|}{$30^{\text {th }}$ BCS } & \multicolumn{2}{|l|}{$31^{\text {st }} \mathrm{BCS}$} \\
\hline & Discipline & Cadre & Discipline & Cadre & Discipline & Cadre & Discipline & Cadre \\
\hline First & $\begin{array}{l}\text { Social } \\
\text { Welfare }\end{array}$ & $\begin{array}{l}\text { Foreign } \\
\text { Affairs }\end{array}$ & M.S.S (Pass) & Police & $\begin{array}{l}\text { B.Sc. } \\
\text { (Computer) }\end{array}$ & $\begin{array}{l}\text { Custom and } \\
\text { Excise }\end{array}$ & $\begin{array}{l}\text { Business } \\
\text { Administration } \\
\text { (IBA, DU) }\end{array}$ & $\begin{array}{l}\text { Administra } \\
\text { tion }\end{array}$ \\
\hline Second & $\begin{array}{l}\text { Computer } \\
\text { Science }\end{array}$ & Police & M.A. (English) & $\begin{array}{l}\text { Foreign } \\
\text { Affairs }\end{array}$ & MBBS & Health & $\begin{array}{l}\text { Business } \\
\text { Administration } \\
\text { (IBA, DU) }\end{array}$ & Police \\
\hline Third & $\begin{array}{l}\text { BSC } \\
\text { Engineering } \\
\text { (Civil) }\end{array}$ & $\begin{array}{l}\text { Foreign } \\
\text { Affairs }\end{array}$ & $\begin{array}{l}\text { M.B.A. } \\
\text { (Accounting) }\end{array}$ & $\begin{array}{l}\text { Foreign } \\
\text { Affairs }\end{array}$ & $\begin{array}{l}\text { Honors } \\
\text { (Economics) }\end{array}$ & $\begin{array}{l}\text { Foreign } \\
\text { Affairs }\end{array}$ & $\begin{array}{l}\text { Social } \quad \text { Welfare } \\
\text { (DU) }\end{array}$ & $\begin{array}{l}\text { Foreign } \\
\text { Affairs }\end{array}$ \\
\hline Fourth & English & $\begin{array}{l}\text { Administrati } \\
\text { on }\end{array}$ & $\begin{array}{l}\text { M.S.S. (Library } \\
\text { and } \\
\text { Information } \\
\text { Science) }\end{array}$ & $\begin{array}{l}\text { Administr } \\
\text { ation }\end{array}$ & $\begin{array}{l}\text { B.Sc. } \\
\text { (Genetics } \\
\text { Engineering) }\end{array}$ & Police & English (DU) & $\begin{array}{l}\text { Administra } \\
\text { tion }\end{array}$ \\
\hline Fifth & $\begin{array}{l}\mathrm{BSC} \\
\text { Engineering } \\
(\mathrm{CSE})\end{array}$ & $\begin{array}{l}\text { Foreign } \\
\text { Affairs }\end{array}$ & $\begin{array}{l}\text { B.Sc. } \\
\text { (Computer) }\end{array}$ & $\begin{array}{l}\text { Foreign } \\
\text { Affairs }\end{array}$ & $\begin{array}{l}\text { Honors } \\
\text { (Sociology) }\end{array}$ & Police & Economics (JU) & $\begin{array}{l}\text { Foreign } \\
\text { Affairs }\end{array}$ \\
\hline Sixth & $\begin{array}{l}\text { BSC } \\
\text { Engineering } \\
\text { (Electrical and } \\
\text { Electronics) }\end{array}$ & $\begin{array}{l}\text { Foreign } \\
\text { Affairs }\end{array}$ & $\begin{array}{l}\text { M.S.S. } \\
\text { (Economics) }\end{array}$ & $\begin{array}{l}\text { Foreign } \\
\text { Affairs }\end{array}$ & $\begin{array}{l}\text { M.S.S. } \\
\text { (Economics) }\end{array}$ & $\begin{array}{l}\text { Foreign } \\
\text { Affairs }\end{array}$ & $\begin{array}{l}\text { Public } \\
\text { Administration } \\
\text { (DU) }\end{array}$ & $\begin{array}{l}\text { Foreign } \\
\text { Affairs }\end{array}$ \\
\hline Seventh & $\begin{array}{l}\text { Public } \\
\text { Administration }\end{array}$ & $\begin{array}{l}\text { Foreign } \\
\text { Affairs }\end{array}$ & $\begin{array}{l}\text { M.Sc. } \\
\text { (Chemistry) }\end{array}$ & $\begin{array}{l}\text { Administr } \\
\text { ation }\end{array}$ & $\begin{array}{l}\text { M.Sc. (Micro } \\
\text { Biology) }\end{array}$ & $\begin{array}{l}\text { Custom and } \\
\text { Excise }\end{array}$ & English (NU) & $\begin{array}{l}\text { Foreign } \\
\text { Affairs }\end{array}$ \\
\hline Eighth & $\begin{array}{l}\text { BSC } \\
\text { Engineering } \\
\text { (Civil) }\end{array}$ & $\begin{array}{l}\text { Foreign } \\
\text { Affairs }\end{array}$ & $\begin{array}{l}\text { Honors } \\
\text { (Computer } \\
\text { Science) }\end{array}$ & $\begin{array}{l}\text { Foreign } \\
\text { Affairs }\end{array}$ & $\begin{array}{l}\text { M.B.A. } \\
\text { (Marketing) }\end{array}$ & $\begin{array}{l}\text { Foreign } \\
\text { Affairs }\end{array}$ & English (DU) & $\begin{array}{l}\text { Administra } \\
\text { tion }\end{array}$ \\
\hline Ninth & MBBS & $\begin{array}{l}\text { Foreign } \\
\text { Affairs }\end{array}$ & $\begin{array}{l}\text { Honors } \\
\text { (Business) }\end{array}$ & $\begin{array}{l}\text { Foreign } \\
\text { Affairs }\end{array}$ & $\begin{array}{l}\text { Honors } \\
\text { (English) }\end{array}$ & $\begin{array}{l}\text { Foreign } \\
\text { Affairs }\end{array}$ & $\begin{array}{l}\text { International } \\
\text { Relations }\end{array}$ & $\begin{array}{l}\text { Administra } \\
\text { tion }\end{array}$ \\
\hline Tenth & Finance & $\begin{array}{l}\text { Administrati } \\
\text { on }\end{array}$ & $\begin{array}{l}\text { Honors } \\
\text { (English) }\end{array}$ & $\begin{array}{l}\text { Foreign } \\
\text { Affairs }\end{array}$ & $\begin{array}{l}\text { Honors } \\
\text { (English) }\end{array}$ & $\begin{array}{l}\text { Foreign } \\
\text { Affairs }\end{array}$ & $\begin{array}{l}\text { Veterinary } \\
\text { Science (RU) }\end{array}$ & $\begin{array}{l}\text { Foreign } \\
\text { Affairs }\end{array}$ \\
\hline
\end{tabular}

Source: Annual Report (2010), Bangladesh Public Service Commission, p.126. 
Annual Report (2011), Bangladesh Public Service Commission, p.85 \& 95.

Annual Report (2012), Bangladesh Public Service Commission, p.81.

Table-A.5: Study Area of the Alumnae

\begin{tabular}{|l|l|l|l|}
\hline \multicolumn{2}{|c|}{ Study Area } & Frequency & Percent \\
\hline & Arts & 86 & 15.4 \\
\hline & Social Science & 113 & 20.3 \\
\hline & Business & 88 & 15.8 \\
\hline & Science & 138 & 24.8 \\
\hline & Engineering & 43 & 7.7 \\
\hline & Technology & 4 & .7 \\
\hline & Agriculture & 76 & 13.6 \\
\hline & Law & 7 & 1.3 \\
\hline & Education & 2 & .4 \\
\hline & Total & $\mathbf{5 5 7}$ & $\mathbf{1 0 0 . 0}$ \\
\hline
\end{tabular}

Source: Analysis of primary data collected from alumnae

Dr Shakhawat Hossain Sarkar is an Associate Professor of the Department of Accounting and Information Systems, Jatiya Kabi Kazi Nazrul Islam University, Bangladesh. He has published a good number of research articles in Professional Journals at home and in abroad. Earlier he has completed PhD as well as MBA, BBS (Honors) in Accounting from University of Rajshahi, Bangladesh.

Dr Syed Zabid Hossain is now Professor and former Chairman of the Department of Accounting and Information Systems at the University of Rajshahi, Bangladesh. He was also the Dean, School of Management and Business Administration and the Pro Vice Chancellor of Khulna University (public), Bangladesh from 2002 to 2005. He has published a good number of research articles in different professional journals in home and abroad. 